\title{
AN ORIGINAL METHOD FOR STRENGTHETING IN ANCIENT STONE DOMES IN SEISMIC REGIONS AND SOLVING CORRESPONDING PROBLEMS OF STRESS-STRAIN STATE
}

\author{
ANALYSIS \\ Moshe Danieli ${ }^{1}$, Arcady Aronchik ${ }^{2}$, Jaacov Bloch ${ }^{3}$ \\ ${ }^{I}$ Department of Civil Engineering, Ariel University, Ariel, Israel \\ ${ }^{2}$ Ring Engineering Ltd., Azour, Israel \\ ${ }^{3}$ Department of Civil Engineering, Ariel University, Ariel, Israel
}

\begin{abstract}
An original method for strengthening ancient stone-built domes by enhancing seismic resistance is proposed in this article. The method consists in casting a thin reinforced concrete shell with a support ring placed on top of the dome. Concrete connection elements project from the shell into the dome body to a specified depth. Resulting reinforcement is achieved by creating an interconnected stone-reinforced concrete structure. Aspects of design, technology, and structural analysis are presented. Stress concentrations in the connection areas are a specific problem of the interconnected structure. While the structure is subjected to static, thermal, and seismic loads, the problems relating to the stress-strain state of the stone dome as well as its dynamic characteristics are also considered. Taking into account forces of adherence on contact surfaces between a stone dome body and a reinforced concrete shell is discussed. Results of the nonlinear static analysis of stress concentration in surrounding connectingmember locations are presented. The structural analysis is made using the finite-element method. The problems are investigated through examples of two actual conservation projects, namely the ancient stone dome in Akhaltsikhe (Georgia) and a dome similar to the Hagia Sophia dome.
\end{abstract}

Keywords: Ancient stone domes, cracking reinforced concrete, Strengthening, Interconnected structure, Stress concentration, Earthquake resistance

\section{INTRODUCTION}

Ancient stone domes are usually architectural works of art. They are a part of buildings, which are usually architectural, and sometimes historical, monuments. These buildings may have utilitarian significance as well. At present, there are a great number of stone domes in the Mediterranean countries, in the Caucasus, and in the East (India, Iran, Turkey and other countries) [1-6]. In the recorded past these territories have come under the influence of severe and destructive earthquakes, accompanied by significant destruction and human victims. The undamaged state of the ancient stone domes is evidence of their relatively high earthquake resistance capacity, mostly because of their axial symmetry, continuity, and closed form in their perimeter. Almost the entire stone dome under the existing loads is in compression, both in the meridian and ring directions. Small tensile ring forces may appear only at its lower part. The stone masonry has good resistance in compression, but poor resistance in tension. This explains the extensive use of stone masonry in domes and the appearance of meridian cracks at the lower part of some of the domes, especially those weakened by openings for light. The appearance of meridian cracks disturbs the integrity of the structure and the dome is, actually, divided into separate independently acting arches in an equilibration state, leading to a decrease in general initial rigidity and load- carrying capacity of the dome [5]. At the end of the XIX century, heavy stone domes were forced out by lighter weight reinforced concrete domes with the appearance of reinforced concrete - the new earthquake-resistant stone-like material with good compression and tension resistance capacity. Use of reinforced concrete provides wide possibilities in strengthening stone domes, as reinforced concrete is a material well compatible with stone masonry. At the same time, in many cases the use of reinforced concrete for strengthening constructions for conservation, enables creating almost invisible elements in order not to distort the look of the monument. It has to be noted that reinforced concrete retains its properties for a long period of time; for example, the dome of the Pantheon of Rome was constructed of concrete 2000 years ago [7].

Preserving architectural-historical monuments and, firstly, ancient stone domes in their original state is the duty of civilized society. International conferences on seismic resistance of structures devote special sections to this problem; it may also be the subject for debate at special international conferences [8]. and other. Their study and summarizing are important. Today there are many research 
projects concerning conservation and restoration of stone domes in the seismic regions and several technologies are used to strengthen stone domes: metal strengthening rings $[9,10,11]$, straining beams $[12,13,14]$, doubling structures [15], carbon fiber cords [16], reinforcement systems consisting of carbon fiber tapes and epoxy raisins (carboniar structural reinforcement system), masonry injection using cement or a polymer solution [4], polymer grids [17], concrete spraying [18,19,20],reinforced concrete jackets [21], and reinforced concrete: one- or two-sided thin coatings [15]. are traditionally applied. Nontraditional components, innovative methods and materials are also applied [21]. All methods of strengthening mentioned above have advantages and disadvantages. Successful application of these methods depends on several factors: importance of the historical monument, its engineering state, safety demands, possible level of technology to fulfill these jobs on the exact site, special considerations of engineers, owners of monuments, and so on. Use of reinforced concrete provides wide possibilities in strengthening of stone domes as reinforced concrete is a material well compatible with stone masonry.

An original method for strengthening (conserving) ancient stone domes is proposed in this article. Aspects of the design, technology and structural analysis are presented. These are described using examples of two actual conservation projects, namely the ancient stone dome in Akhaltsikhe (Fig. 1) (in Georgia) and one similar to the Hagia Sophia (Istanbul, Turkey) dome in proportions.

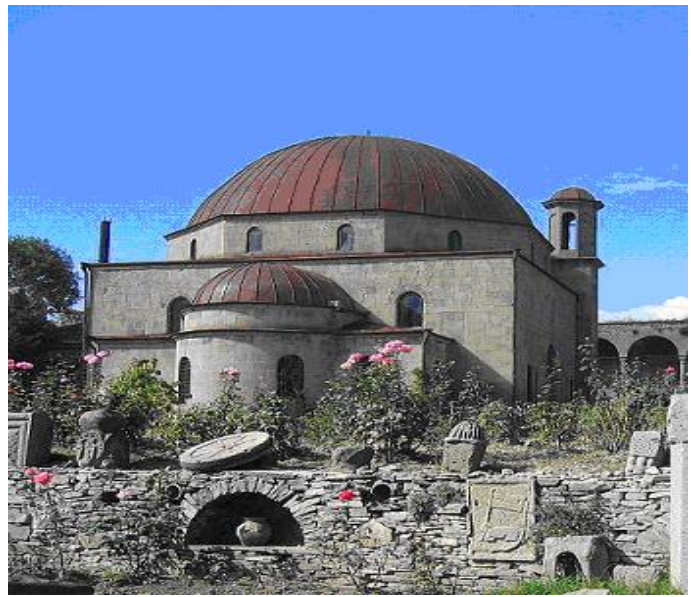

Fig-1: Dome (former mosque) in Akhaltsikhe

\section{PROPOSED METHOD \\ STRENGTHENING OF STONE DOMES}

FOR

\subsection{Strengthening Structure}

There is a need for conservation, in most cases, when cracks or any other damage have been detected, because of the historical and architectural importance of the ancient stone domes. Strengthening is also needed to withstand seismic loads, where severe earthquakes are anticipated. An original strengthening structure is proposed hereby (Fig. 2) (according to proposed design for strengthening the stone dome of Akhaltsikhe; Fig. 1, 3,a).
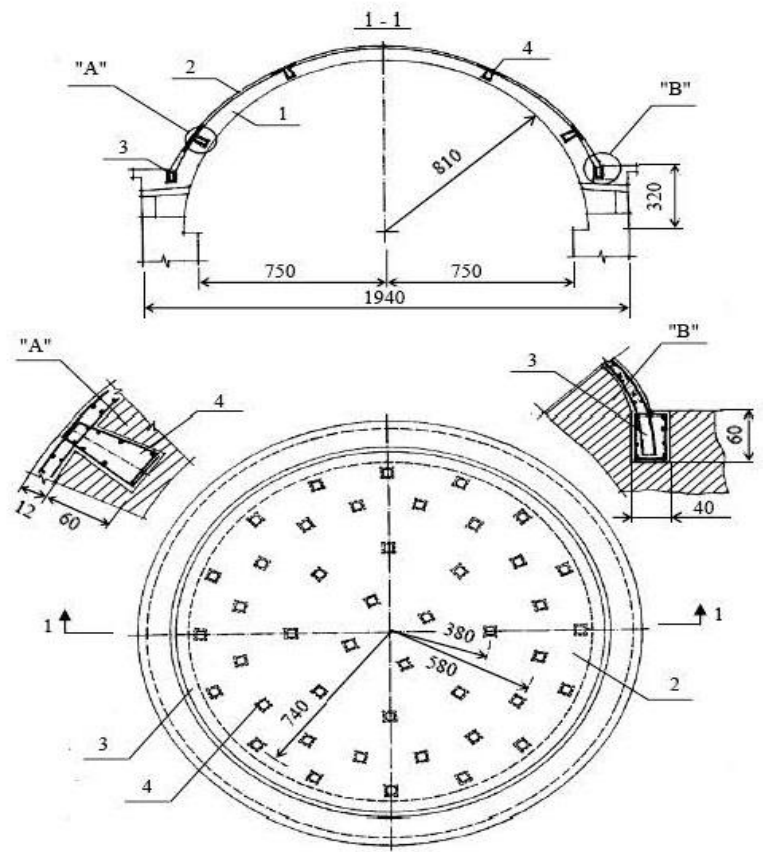

Fig-2: Structure for Dome strengthening.

1 - stone dome; 2 - reinforced concrete shell;

3 - supporting ring; 4 - connection elements

It is proposed to carry out the strengthening of the existing dome from its outer surface in order to preserve the appearance of the interior authentic surface of the dome; for example, the stone dome of Akhaltsikhe with its stone masonry containing cracks in the lower part (Fig. 3b, c) and the Hagia Sophia Dome, with its rich colorfully ribbed decoration on the inner surface (Fig. 4). Execution of the construction work in such manner leads to some advantages: the strengthening structure is located under the roof covering and the stone dome is used as scaffolding for the structure.

The proposed strengthening structure consists of a thinwalled reinforced concrete shell, cast on top of the existing stone dome, and a supporting ring at its bottom (Fig. 2, dimensions and reinforcement are given with reference to the dome in Akhaltsikhe). The reinforced concrete supporting ring is placed in a groove engraved into the stone. The necessary connection to provide interaction of the stone dome and the reinforced concrete shell is achieved by means of reinforced concrete connection elements. These elements (like pins), in the shape of a truncated pyramid or cone (with the large base in the stone dome), protrude from the reinforced concrete shell and penetrate into the stone dome, distributed through the entire dome surface. These connection elements may be made using various types of reinforced concrete. An additional linkage is the adherence force between the neighboring surfaces of the stone dome and reinforced concrete shell. The upper surface of the stone dome may be roughened to increase this force. 


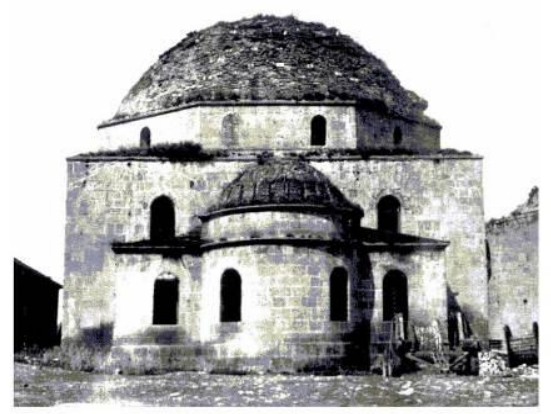

b

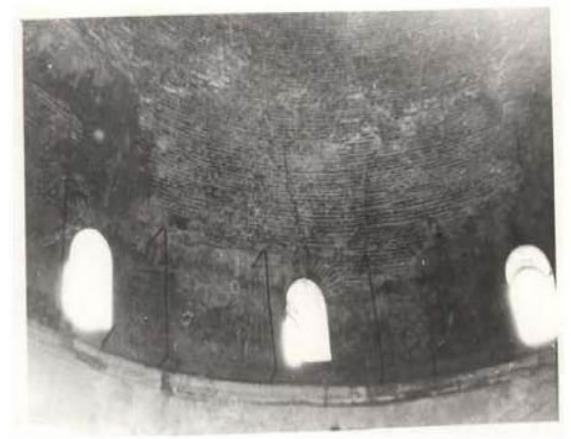

$\mathrm{c}$

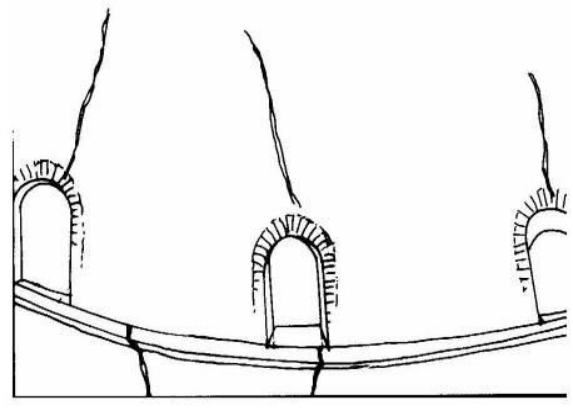

Fig-3: Dome (former mosque) in Ahalthsihe a - view without roof; b, c - cracks at the inner surface, $\mathrm{b}$ - picture, $\mathrm{c}$ - scheme

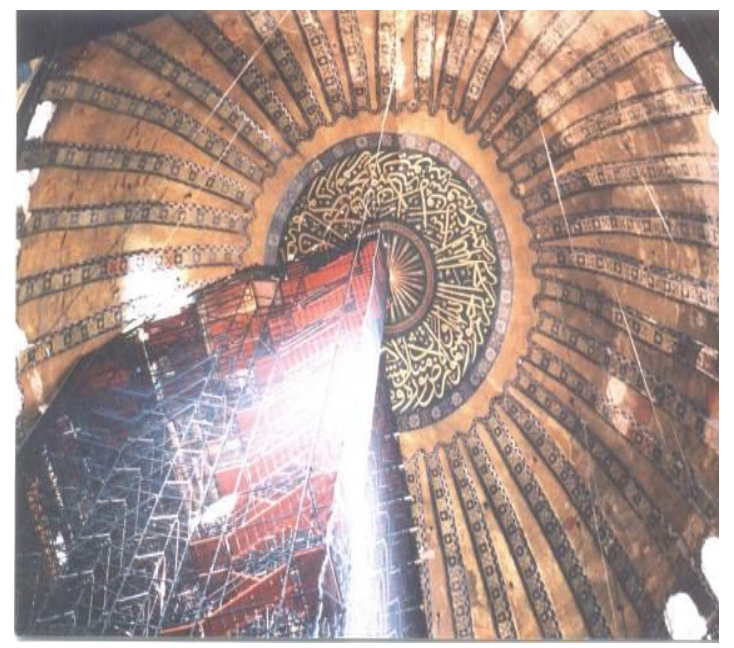

Fig-4: Inner view of Hagia Sophia dome
Thus, the interconnected stone-reinforced concrete shell is achieved. The application of the proposed method enables strengthening a stone dome through practically all its thickness, which is important, as seismic action could be from a non-predictable direction. Concentration of stresses at zones of the connection elements is a characteristic feature of the stress-strain state for such structures. The difference in modulus of elasticity for materials of interconnected structures and the significant difference in (Fig. 3). their material strength in tension and compression should be taken into account. The stresses in a stone dome may be decreased significantly as a result of strengthening by the proposed method; it could significantly raise the earthquake resistance of a stone dome; the thrust forces are perceived by the reinforced concrete ring and so the dome supporting structures are relieved of effects from horizontal forces. It should be noted that the thickness of the reinforced concrete shell is estimated not by demands of stability and strength conditions for itself, but mainly by the possibility for load redistribution between the stone dome and reinforced concrete shell. It depends on the necessary degree of unloading for the stone dome. Thickness of $6-12 \mathrm{~cm}$ could be recommended for the reinforced concrete shell in most cases of stone dome spans. At the same time, total vertical and seismic loadings are increased about 15-20\%, as a result of casting the reinforced concrete shell. An actual example of a similar strengthening for a reinforced concrete shell $10 \mathrm{~m}$ diameter with a very moderate slope is given by Danielashvili et al. [22].

\subsection{Execution of Strengthening}

The sequence of work to execute strengthening by our proposed method is the following: placing temporary supports as safety scaffolds; striping the upper surface of the dome down to stone masonry with proper processing (for example, in the case of Akhaltsikhe dome, according to the proposed design for its strengthening), restoration of existing steps at upper stone masonry surface (Fig. 1); moistening with water before casting the concrete shell (to increase the adhesion between the masonry of the existing dome and new casting concrete); cleaning of cracks (about $0.2-0.5 \mathrm{~cm}$ at the upper surface of the dome), filling of crack space with a pressurized cement-lime-sand composition; engraving of pyramidal sockets (with base inward) in the stone dome throughout the entire surface in staggered rows in meridian and ring directions; priming treatment of the inner surface of the socket in the stone dome with cement mortar or concrete; creating connecting pins starting from the reinforced concrete shell: introducing steel reinforced bars into prepared zones in the stone dome and connecting them with the reinforced mesh of the shell; drilling several holes in walls from its exterior, to cast a reinforced concrete supporting ring beam (proportions of this ring beam and its proper location are estimated by analysis); the supporting ring beam could reach the upper boundary of window openings by its section height; reinforcement of the concrete shell and supporting ring is placed and fixed; casting of concrete for shell and supporting ring is executed above the stone dome (with increased thickness at the near-contour zone); curing of concrete. 


\section{DOMES}

\subsection{Stone Dome in Akhaltsikhe}

The building of the former mosque in the town of Akhaltsikhe was constructed in 1758 (Fig. 3). At present, it is an architectural-historical monument located in South Georgia (Fig.1). The maximum anticipated earthquake in this region, according to the Richter scale, is estimated at a magnitude $\mathrm{M}_{\mathrm{s} \max }=7.0$ [23]. It should be noted that during the period of its existence, Akhaltsikhe endured several significant earthquakes, including the Akhalkalakhi Earthquake (Georgia, December 31, 1899, Ms. = 5.4; Akhaltsikhe is about $45 \mathrm{~km}$ from Akhalkalakhi), Spitak Earthquake (Armenia, December 7, 1988, Ms = 6.9-7.0; about $125 \mathrm{~km}$ from Akhaltsikhe), and Racha Earthquake (Georgia, April 29, 1991, Ms = 6.9; about $100 \mathrm{~km}$ from Akhaltsikhe).

The stone dome in Akhaltsikhe (Fig. 1) is one of the most significant stone domes of its size among those existing today in Georgia. The inner diameter of the supporting contour of the dome is about $16 \mathrm{~m}$; inner height (rise) is about $8 \mathrm{~m}$, thickness of the walls is $0.6-0.8 \mathrm{~m}$. The dome was constructed from thin clay bricks with dimensions of $24 \times 24 \times 4 \mathrm{~cm}$, on a lime-clay mortar. The brick edges stand out horizontally in steps on the upper surface of the dome (Fig. 3a). The dome has typical cracks originating from the supporting zone in the meridian direction and opening crack width on the lower surface of 1.5-2.0 cm (Fig. 3b, c). The cracks are caused by the existence of tensile ring stresses (about $0.044 \mathrm{MPa}$ ) as a result of self-weight action; additional weak zones of a dome are created by window openings (Fig. 3b, c). There is a clear need for dome conservation and strengthening, taking into account the history and architecture of the important building, the existence of developed cracks, and the need to save it from seismic loads during possible severe earthquakes without significant damage. To preserve the inner ancient look of the dome in its present state (with cracks in the brick masonry), it is proposed to carry out strengthening of the dome according to the proposed method - with a new reinforced concrete shell above the upper surface of the stone dome and connected with it.

Input data for analysis are taken from results of inspection and measures, according to design proposals: for stone dome: density $1.8 \mathrm{t} / \mathrm{m}^{3}$; Module of Deformation $\mathrm{E}=1.5 \times 10^{3}$ $\mathrm{MPa}$; span of a dome $\mathrm{D}=15.8 \mathrm{~m}$; height (at apex) $\mathrm{f}=4.9 \mathrm{~m}$ (above the level of the top of light openings); thickness of stone dome - from $0.8 \mathrm{~m}$ (at bottom zones) to $0.7 \mathrm{~m}$ (at top zone, apex). For concrete shell and concrete connection elements: density $2.4 \mathrm{t} / \mathrm{m}^{3}$; compressive strength for concrete $30 \mathrm{MPa} ; \mathrm{E}=3.0 \times 10^{4} \mathrm{MPa}$; span of a shell $-\mathrm{D}=$ $16.7 \mathrm{~m}$; height (at apex) $\mathrm{f}=5.26 \mathrm{~m}$; thickness of a shell 0.12 $\mathrm{m}$ (at zone of supporting ring $0.20 \mathrm{~m}$ ); cross-section of ring beam $\mathrm{b} \times \mathrm{h}=0.4 \times 0.6 \mathrm{~m}$; for concrete connection elements (joints): cross-section from $0.3 \times 0.3 \mathrm{~m}$ at surface of concrete shell, up to $0.45 \times 0.45 \mathrm{~m}$ at bottom of pyramidal sockets in a stone dome; length $0.6 \mathrm{~m}$. Total number of connection elements -44 . Connection joints are distributed throughout the dome surface by 4 circular lines.

\subsection{Dome Similar to Hagia Sophia Main Dome by}

\section{Proportions}

The Hagia Sophia as a whole construction and its main dome in particular, has been considered a great structure of the civilized world for almost 15 centuries. Thus, many publications are devoted to its study and research, for example [1,2,6,24-28]. Authors of this article used some information about the main Dome of Hagia Sophia's proportions to study limitations for the proposed method of strengthening, only.

Input data for a dome similar to Hagia Sophia's stone dome (geometry, characteristics of materials, and so on) were taken from [1,2,24,25,26]: density $1.8 \mathrm{t} / \mathrm{m}^{3} ; \mathrm{E}=1.5 \times 10^{3}$ $\mathrm{MPa}$; span of dome $\mathrm{D}=32 \mathrm{~m}$; height to apex $\mathrm{f} \approx 14.8 \mathrm{~m}$; thickness of stone masonry shell from $0.8 \mathrm{~m}$ (at bottom zones) to $0.7 \mathrm{~m}$ (at top zone, apex). For concrete shell and connection elements: density - $2.4 \mathrm{t} / \mathrm{m}^{3}$; compressive strength for concrete $-30 \mathrm{MPa}$; $\mathrm{E}=3.0 \times 10^{4} \mathrm{MPa}$; span of shell $-\mathrm{D}=32.9 \mathrm{~m}$; height to apex $\mathrm{f} \approx 15.25 \mathrm{~m}$; thickness $0.16 \mathrm{~m}$ (support ring beam $0.2 \mathrm{~m}$ ); cross-section of ring beam $b \times h=0.4 \times 0.6 \mathrm{~m}$. For concrete connection elements (joints): cross-section is from $0.5 \times 0.5 \mathrm{~m}$ at the surface of the reinforcement shell to $0.6 \times 0.6 \mathrm{~m}$ at the bottom of the pyramidal sockets in the stone dome; length $0.6 \mathrm{~m}$. Total number of connection elements (joints) -94 . Connection joints are distributed throughout the dome surface by six circular lines.

\section{SOME PECULIARITIES OF FEM STRUCTURAL SIMULATION FOR SOLVING PROBLEMS}

\subsection{Overall Remarks}

The abilities of today's software for the finite element method are so high that it is quite easy to create a structural model for a whole building. But, on the other hand, the stages of preliminary testing of such a large model and processing of obtained results becomes difficult and exhausting, even using powerful postprocessor software systems. As a result, it sometimes leads to methodological mistakes and to loss of accuracy in the performed analysis. An alternative solution is to use several models for some stages of analysis: stage 1 - for preliminary overall analysis and then stages 2 and 3 for more detailed analysis for some special zones and problems. For ancient structures it is very important to take into consideration special properties and characteristics of the structure due its changes during the period of existence (e.g., after partial damages, repairs), actual state of the materials (presence of cracks), and soil conditions. It could be mentioned that the dynamic characteristics of a structure (periods of free vibrations) obtained by field investigations and by numerical analysis often show significant differences (1.8-2.0 times and even more). So, the stage of "calibration" - updating of structural models by comparison with results of field investigations seems to be very important [29]. 


\subsection{Short Description of the Models (Stone Dome} in Akhaltsikhe and a Dome Similar to that of Hagia Sophia's Dome)

Two existing ancient stone domes were selected as prototypes for performing a series of structural analyses the stone dome in Akhaltsikhe (Fig. 5a) and an analog of the main dome of Hagia Sophia (Fig. 5b). These two domes differ significantly from each other by geometric size and properties (diameter, rise, thickness, and their ratios) and cover the proportions of most types of widespread stone domes. The authors would like to outline that they are familiar with the sophisticated problems of investigations of the stress-strain state of Hagia Sophia stone domes in seismic conditions. They tried to check the possibility of using the proposed method of strengthening for a dome with proportions like Hagia Sophia only. Three types of finite element models were used for a series of structural analyses (static, dynamic, and thermal analysis): (1) a simplified model of the main structural elements for the whole building (stage 1); (2) detail model of a stone dome only (stage 2A) and detail model of stone dome connected with concrete shell by connection joints (stage 2B), for example, used detailed model and normal ring stress Nx diagrams due to vertical and seismic loads are presented in Fig. 6; (3) auxiliary detail model for a fragment of supporting zone of stone dome only (zones including window holes and supporting ring beam, stage 3 ).
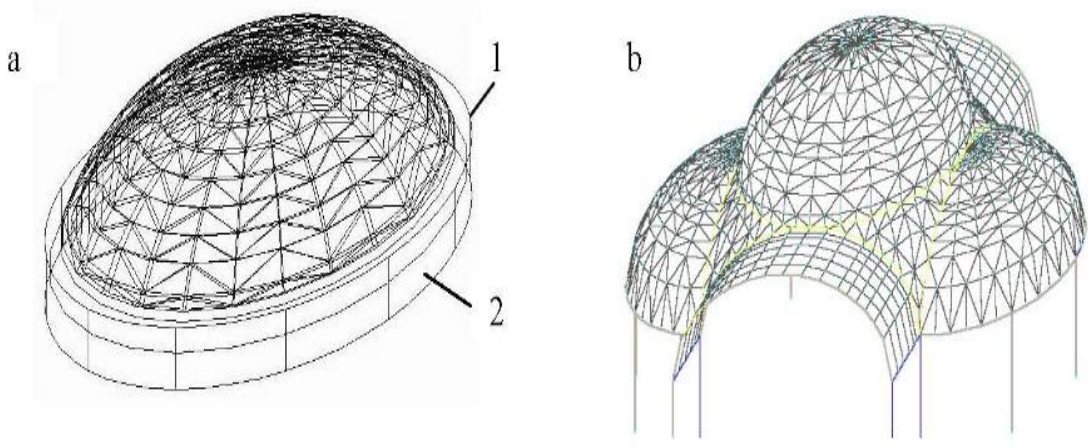

Fig-5: Finite element structural models of domes a-dome in Ahalthsihe; 1, 2-external ring beams. $\mathrm{b}$ - dome similar to Hagia Sophia dome (preliminary model)
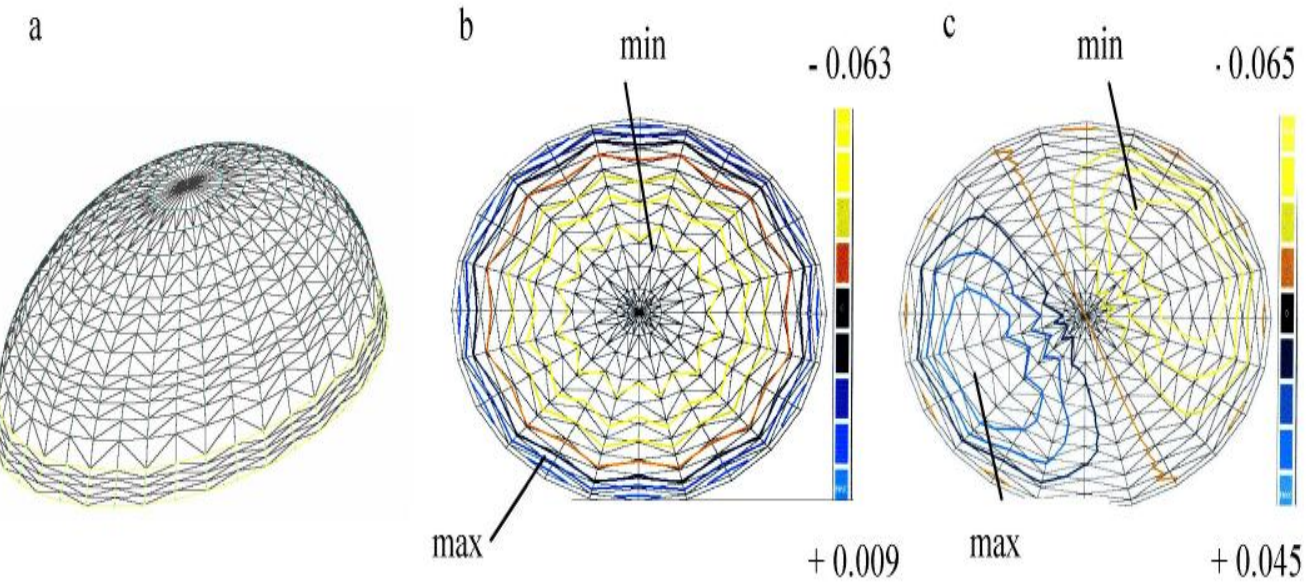

Fig-6: Finite element structural model of stone dome connected with concrete shell a- detail model; b, c - diagrams of normal ring stresses, Nx, MPa, b-due vertical load, c-due seismic load

Simplified model (stage 1) consisted of triangle plane shell finite elements to represent surfaces of a central dome, halfdomes, cylindrical shells; frame type bar finite elements (with shear deformations also) were used to represent supporting ring beam, columns; spring type finite elements were used to represent the influence of surrounding structures (e.g., small periphery shells, walls) in vertical and horizontal directions. The aim of using of this simplified model was to get some auxiliary information (rigidity characteristics of springs, internal forces in these spring elements) which was then used for models $2 \mathrm{~A}$ and $2 \mathrm{~B}$. For example, general characteristics of a simplified model (stage 
$1)$ : number of nodes - 1160; number of elements -2152 (1520 - shell elements); number of rigidity types - 80; number of partial masses - 86; number of vibration modes 6 (3-D vibrations). Detailed model (stage 2) of stone dome consisted of triangle plane shell finite elements to represent surface of a central dome, frame type bar finite elements (with shear deformations also) to represent supporting ring beam including local zones between window holes, spring type finite elements to represent influence of surrounding structures (including half-domes, cylindrical shells, columns, periphery shells, walls, and so on). Auxiliary detailed model (stage 3 ) of a stone dome fragment included groups of triangle plane shell finite elements to represent the surface of a dome, frame type bar finite elements to simulate the supporting ring beam, and spring type finite elements to represent influence of surrounding structures. The main results of this analysis - values of equivalent rigidities of frame type bar finite elements used to simulate zones with openings for models $2 \mathrm{~A}$ and $2 \mathrm{~B}$.

\subsection{Problem of Interconnections for Existing Stone}

\section{Dome and Reinforced Concrete Shell}

The main peculiarity in these models is simulation interaction between two structures - existing stone dome and new reinforced concrete shell. Interaction between these two structures was realized by special concrete connectors and by neighboring surfaces of stone and concrete.

\subsubsection{Concrete Connectors}

Special type finite elements (spring type elements) were used to describe these connections in zones of concrete connection elements. The rigidity characteristics of these elements were estimated according to their dimensions and properties of their material. Internal forces in springs (obtained according to structural analysis) were then transformed into axial and shear forces in concrete connecting elements. The total number of connection elements varied for the series of performed structural analyses (44-110 connections).

\subsubsection{Problem of Interconnection between \\ Neighboring Surfaces of Stone and Concrete}

The same structural finite element models, as described above, were used as the basis models for analysis to study the problem of full interconnection between neighboring surfaces for existing stone dome and reinforced concrete shells. These models were completed by groups of additional special spring type finite elements in three main directions of surfaces. These spring type elements were introduced at every two neighboring nodes of concrete and stone structure surfaces. Such additional elements allowed simulating contact between the two surfaces. Total number of connecting pairs of nodes was 320 . The rigidity characteristics of springs were estimated according to corresponding "loading area" and modulus of deformation for contact zone material. This modulus was taken as 0.3 for the initial modulus of deformation for stone; the same proportion (0.3) was also taken for strength characteristics.
Reactions of springs obtained from structural analysis were then transferred into normal and shear stresses by spreading reactions throw corresponding "loading areas".

\subsubsection{Physical Non-Linear Problems for}

\section{Connection Zones}

It is known that high levels of stress and a complex character of stress distribution are typical of connection zones [30]. On the other hand, fracture often did not occur practically at connection zones for these levels of stresses. This could be explained by non-linear behavior of material and redistribution of stresses. So, it was decided to perform a series of non-linear structural analyses for connection zones. The series of non-linear structural analyses are performed by the finite-element method (FEM) using the "Lira" and "MAG STR" software (NIIASS, Kiev, Ukraine), as these packages include corresponding options: libraries of physical non-linear elements and step-by-step loading procedures. Comparisons of these packages with similar ones can be found at www.lira.com.ua.

Three types of loading step procedures were tested for preliminary use to solve the mentioned problem: (1) simple step procedure; (2) step procedure taking into account discrepancy at a following step with a single iteration for correction on a step; (3) step procedure taking into account discrepancy at a following step with repeating iterations (until convergence criteria is reached at every step). Simple step loading procedure (1) of non-linear loading processor "STEP" was selected and used finally.

\section{SOME RESULTS OF STRUCTURAL ANALYSIS AND DISCUSSION}

\subsection{Preliminary Remarks}

To study the stress-strain state characteristics of the strengthened structure, as well as to estimate the efficiency of the proposed strengthening method, a series of analyses were executed by FEM. These series included: analysis of the original stone dome only and the stone dome connected with a reinforced concrete shell for vertical (self-weight), seismic, and thermal loads and for varying numbers of connecting elements, as well as analysis of problems of stress concentration around the connecting elements; the problem of full interconnection between two neighboring surfaces (new concrete and old stone domes) were studied also. Horizontal Seismic loads were estimated using PGA value equal to $0.4 \mathrm{~g}$. This high value was used because of the importance of the architectural-historical monuments. That reasoning may be found at $[21,31,32,33]$. Study of the problems was performed by way of numerical analysis on a project of conserving the existing ancient stone dome in Akhaltsikhe and one similar to the Hagia Sophia dome. In addition, the following analyses were performed: immediately for stone dome for influence of the loading from the self-weight, according to the approximate-shell theory of Geckeler [34]. (preliminary control analysis); design of reinforced concrete shell for influence of load 
from the combined self-weight of the strengthened (connected) structure (intensity of combined estimated load at the top of the dome is $20 \mathrm{kN} / \mathrm{m}^{2}$ ), according to the theories of limit analysis [35].

\subsection{Main Results for Vertical and Seismic Loads}

The main results of structural analysis are presented in Tables 1 and 2. The analysis of the stone dome connected with the reinforced concrete shell was compared with that of a stone dome alone.

Stone dome in Akhaltsikhe (Table 1): for vertical loads: for example, membrane compression stresses were reduced by $25-30 \%$, membrane tension stresses were reduced by $75-$ 80\%; for seismic loads: maximum membrane stresses (+/-) were reduced by $95 \%$, maximum vertical and horizontal displacements (+/-) were reduced by about $50 \%$.

Stone dome similar to the Hagia Sophia dome (Table 2): for vertical loads: maximum horizontal displacements of a ring beam were reduced by $50 \%$ - meaning that horizontal reactions that are transferred from the dome to columns and surrounding structures also decrease significantly; membrane compression stresses are reduced by $15-25 \%$; for seismic loads: membrane stresses (+/-) are reduced by a factor of 1.5-2.2 times; maximum horizontal displacements of a dome are reduced about 4.2 times.

The membrane stresses in the meridian direction due to seismic, horizontal loads are much lower than those due to vertical loads (self and live loads), while the parallel (ring) stresses are very much higher. The obtained results show the efficiency of the proposed strengthening method.

\subsection{Thermal Problems}

A series of structural FEM analyses using the same models as described above (stone dome only, stone dome connected with concrete shell) were performed for the following thermal problems: analysis of a stone dome for uniform thermal gradient (positive or negative) $-20^{\circ} \mathrm{C}$; analysis of a stone dome for non-uniform thermal gradient: positive gradient for internal surface - plus $20^{\circ} \mathrm{C}$; negative gradient for external surface - minus $20^{\circ} \mathrm{C}$. The following values of thermal expansion coefficient were taken: material of stone dome $\alpha=0.5 \times 10^{-5}$, concrete shell and connection elements $\alpha=1.0 \times 10^{-5}$. The main results of the performed analysis (stone dome only, stone dome connected with concrete shell) are presented in [36]. It was found that values of deformations and stresses due to thermal loads are of the same order as the corresponding values due to vertical and seismic loads. Therefore, for such problems it is important to take into consideration the thermal loads as independent load cases and to include them in load combinations.

\subsection{Problem of Full Interconnection between}

\section{Neighboring Surfaces of Concrete and Stone Shells}

The problem of full interconnection between two neighboring surfaces (new concrete and old stone domes) is a special one to be investigated. It is important to find possible changes in the stress-strain state of the stone dome and reinforced concrete connecting elements in case of interconnected neighboring surfaces. These changes are to be studied for domes with various spans, as the effect of interconnection might vary depending on dome span. A series of structural analyses were performed to find the effect of interconnection of stone and concrete surfaces. It included the following variations: stone dome and concrete shells connected by neighboring surfaces only, by neighboring surfaces, and by connecting elements. Analyses were performed for vertical and seismic load and for two domes: the dome in Akhaltsikhe and a dome similar to the Hagia Sophia one. The main results of analysis are presented for vertical and seismic loads in Tables 1 and 2 and Figure 7. For convenience of comparison, these tables include also the main parameters for the state of a stone dome in two variations investigated previously: stone dome only and a stone dome connected to a concrete shell by connection elements only. A stone dome connected to a concrete shell by their neighboring surfaces was compared with the same dome but connected by means of concrete connection elements only. The following observations were made: internal forces in connecting elements decreased significantly in the case of connected surfaces.

This may be of special importance in large-span domes. At the same time, total stresses (normal and bending) in stone domes, dynamic characteristics, and deformations changed considerably less. On the other hand, maximum allowable tension stresses at surface of contact are limited. In case of need, the number of concrete connection elements must be increased. Adhesive forces at contact surfaces and connection elements reduce tension stresses and deformations of the stone dome significantly, leading to a significant increase of seismic resistance. So, it seems that the effect of surface interconnection is helpful.

\subsection{Connecting Elements}

\subsubsection{Influence of a Number of Connecting}

\section{Elements}

A special series of structural analyses were performed to study the influence of the number of connecting elements and their distribution through the dome surface [37]. The model of a dome similar to the Hagia Sophia central dome was used for these series. Its essence lies in the possibility of regulation of the stress-strain state of the stone dome by changing the number and location of connecting members. Stresses in the stone dome could be reduced significantly by proper selection of the number and location of connection elements.

Obtained results show the efficiency of the proposed strengthening method. The main results of analysis (values of internal forces in connections) are presented in Table 3. 


\subsubsection{Stress Concentration Problem: Physical Non-}

\section{Linear Problems.}

The structural models were two-dimensional extracts of a structure which consisted of a reinforced concrete connecting element and surrounding zones of the stone dome. Two main schemes of load were examined for a connecting element: 1-axial load, 2-pure shear (Fig. 8a); components of the stressed state are presented in Figure 8b. Two linear test problems were solved as a preliminary to more precisely defining the parameters of a finite-element mesh. The influence of mesh density was tested here: meshes of $64 \times 42$ elements and $34 \times 22$ elements were used. Finally, a mesh of $34 \times 22$ elements was chosen for nonlinear structural analysis, according to the results of these preliminary test problems. The non-linear structural model of a fragment consisted of a non-linear plane triangular and rectangular finite elements; total number of nodes is 960 , total number of finite elements - 1001. "Deformation-stress" streak lines with a number of zones - 18 were used for the description of non-linear properties of materials (stone, concrete). Stress-strain diagrams of materials are presented in Figure 7C. The stepby-step load procedure included 22 steps of load, with correction of results at every step. The state of the material was checked at every load step during load increases. Output information about the state of the material and values of deformations and stresses is available; it allowed us to follow the progress of damage accumulation and the effects of stress redistribution and estimate dimensions of zones with non-elastic deformations. The Balandin-Geniev modified strength theory [38]. was used as a theory of material strength. The main results of the series of FEM analyses are presented in at Figures 8, 9 and 10. 
Table -1: Dome in Akhaltsikhe. Main results of analysis

\begin{tabular}{|c|c|c|c|c|}
\hline \multirow[t]{2}{*}{ Parameters } & \multirow{2}{*}{$\begin{array}{l}\text { Original stone } \\
\text { dome only* }\end{array}$} & \multicolumn{3}{|c|}{ Dome and shell interconnected by $* *$} \\
\hline & & $\begin{array}{l}\text { adherence } \\
\text { forces only }\end{array}$ & $\begin{array}{l}\text { connection } \\
\text { elements only }\end{array}$ & $\begin{array}{l}\text { adherence forces } \\
\text { +connection } \\
\text { elements }\end{array}$ \\
\hline \multicolumn{5}{|l|}{ Maximum values: vertical loads/seismic loads*** } \\
\hline $\begin{array}{l}\text { Periods of free vibrations, sec: } \\
\mathrm{T}_{1} \\
\mathrm{~T}_{2} \\
\mathrm{~T}_{3}\end{array}$ & $\begin{array}{l}/ 0.239 \\
/ 0.129 \\
/ 0.072\end{array}$ & $\begin{array}{l}/ 0.235 \\
/ 0.127 \\
/ 0.048\end{array}$ & $\begin{array}{l}/ 0.235 \\
/ 0.127 \\
/ 0.048\end{array}$ & $\begin{array}{l}/ 0.234 \\
/ 0.127 \\
/ 0.047\end{array}$ \\
\hline $\begin{array}{l}\text { Maximum displacements , mm } \\
\text { - vertical, w } \\
\text { - horizontal, u }\end{array}$ & $\begin{array}{l}2.24 / \\
0.72 / 4.79\end{array}$ & $\begin{array}{l}1.12 / \\
0.26 / 4.42\end{array}$ & $\begin{array}{l}1.40 / \\
0.257 / 4.44\end{array}$ & $\begin{array}{l}1.08 / \\
0.255 / 4.36\end{array}$ \\
\hline $\begin{array}{l}\text { Max. membrane stresses in stone dome, } \mathrm{MPa}, \\
\text { - in meridian direction: } \\
\sigma_{\mathrm{Ny}}(+) \\
\sigma_{\mathrm{Ny}}(-) \\
\text { - in ring direction: } \\
\sigma_{\mathrm{NX}}(+) \\
\sigma_{\mathrm{Nx}}(-)\end{array}$ & $\begin{array}{l}/ 0.070 \\
0.360 / 0.050 \\
0.082 / 0.070 \\
0.099 / 0.109\end{array}$ & $\begin{array}{l}/ 0.041 \\
0.244 / 0.003 \\
0.009 / 0.044 \\
0.020 / 0.051\end{array}$ & $\begin{array}{l}/ 0.035 \\
0.292 / 0.007 \\
0.009 / 0.045 \\
0.063 / 0.065\end{array}$ & $\begin{array}{l}/ 0.042 \\
0.283 / 0.001 \\
0.014 / 0.048 \\
0.022 / 0.049\end{array}$ \\
\hline $\begin{array}{l}\text { Max. bending stresses in stone dome, } \mathrm{MPa} \\
\text { - in meridian direction: } \\
\mathrm{m}_{\mathrm{y}}(+) \\
\mathrm{m}_{\mathrm{y}}(-) \\
\text { - in ring direction: } \\
\mathrm{m}_{\mathrm{x}}(+) \\
\mathrm{m}_{\mathrm{x}}(-)\end{array}$ & $\begin{array}{l}0.620 / 0.685 \\
0.110 / 0.017 \\
0.203 / 0.191 \\
0.049 / 0.002\end{array}$ & $\begin{array}{l}0.330 / 1.048 \\
0.095 / 0.034 \\
0.133 / 0.256 \\
0.018 / 0.008\end{array}$ & $\begin{array}{l}0.349 / 1.007 \\
0.078 / 0.027 \\
0.135 / 0.241 \\
0.007 / 0.013\end{array}$ & $\begin{array}{l}0.326 / 1.039 \\
0.081 / 0.073 \\
0.130 / 0.247 \\
0.017 / 0.007\end{array}$ \\
\hline $\begin{array}{l}\text { Internal forces in stone ring beams : } \\
\text { - ring beam } 1 \text { : } \\
\mathrm{N}, \mathrm{kN} \\
\mathrm{Q}, \mathrm{kN} \\
\mathrm{M}_{\mathrm{y}}, \mathrm{kN} \cdot \mathrm{m} \\
\mathrm{M}_{\mathrm{z}}, \mathrm{kN} \cdot \mathrm{m} \\
\text { - ring beam } 2: \mathrm{N}, \mathrm{kN} \\
\mathrm{Q}, \mathrm{kN} \\
\mathrm{M}, \mathrm{kN} \cdot \mathrm{m}\end{array}$ & $\begin{array}{l}24.5 / 78.0 \\
12.0 / 89.0 \\
17.0 / 175.4 \\
10.0 / \\
+114.0 / \pm 55.0 \\
\pm 37.0 / 60.0 \\
-42.0 / 131.0\end{array}$ & $\begin{array}{l}11.2 / 77.0 \\
13.0 / 90.0 \\
16.1 / 179.3 \\
+41.0 / 34.0 \\
\pm 25.0 / 62.0 \\
\pm 29.0 / 134.0\end{array}$ & $\begin{array}{l}11.4 / 77.0 \\
13.0 / 89.0 \\
16.0 / 178.4 \\
7.0 / \\
+41.0 / 33.0 \\
\pm 24.0 / 61.0 \\
\pm 29.0 / 132.0\end{array}$ & $\begin{array}{l}+9.0 / 77.0 \\
+13.0 / \pm 89.0 \\
+16.0 / 177.0 \\
7.5 / \\
+39.8 \pm 36.0 \\
\pm 27.062 .0 \\
\pm 23.0 / \pm 134.0\end{array}$ \\
\hline $\begin{array}{l}\text { External forces in stone piers: } \\
\mathrm{N}, \mathrm{kN} \\
\mathrm{Q}, \mathrm{kN} \\
\mathrm{M}, \mathrm{kN} \cdot \mathrm{m}\end{array}$ & $\begin{array}{l}764.0 / 147.0 \\
71.0 / 120.0 \\
161.0 / 134.0\end{array}$ & $\begin{array}{l}764.0 / 166.0 \\
37.0 / \\
92.0 / 247.0\end{array}$ & $\begin{array}{l}765.0 / 166.0 \\
40.5 / \\
100.0 / 250.0\end{array}$ & $\begin{array}{l}764.0 / 167.0 \\
39.0 / 17.0 \\
95.0 / 255.0\end{array}$ \\
\hline $\begin{array}{l}\text { Maximum stresses in surface of contact , } \\
\mathrm{kN} / \mathrm{m}^{2}: \\
\sigma_{\mathrm{z}} \\
\tau_{\mathrm{xy}}\end{array}$ & $\begin{array}{l}- \\
- \\
-\end{array}$ & $\begin{array}{l}+99 / 81 \\
-82 / \\
-/ 99 \\
-52 /\end{array}$ & $\begin{array}{l}- \\
- \\
-\end{array}$ & $\begin{array}{l}+103 / 43 \\
-1 \\
+44 / 47 \\
-10 /\end{array}$ \\
\hline $\begin{array}{l}\text { Maximum values of internal forces in } \\
\text { connection elements, } \mathrm{kN} \text { : } \\
\text { - axial forces, } \mathrm{N}_{\mathrm{z}} \\
\text { - } \text { shear forces, } \mathrm{N}_{\mathrm{x}}\left(\mathrm{N}_{\mathrm{y}}\right) \\
\end{array}$ & & & $\begin{array}{l}98.3 / 71.0 \\
25.0 / 105.0\end{array}$ & $\begin{array}{l}-132.0 / 51.0 \\
+18.5 / 83.0\end{array}$ \\
\hline
\end{tabular}

\section{Remarks:}

* Load from weight of stone dome

** Load from weight of reinforced concrete shell + weight of stone dome

$* * *$ Ground acceleration $-0.4 \mathrm{~g}$ 
Table -2: Similar to Hagia Sophia dome. Main results of structural analysis of stone dome

\begin{tabular}{|c|c|c|c|c|}
\hline \multirow[b]{2}{*}{ Parameters } & \multirow[b]{2}{*}{$\begin{array}{l}\text { Original } \\
\text { stone dome } \\
\text { only* }\end{array}$} & \multicolumn{3}{|c|}{ Dome and shell interconnected by** } \\
\hline & & $\begin{array}{l}\text { Adherence } \\
\text { forces only }\end{array}$ & $\begin{array}{l}\text { Connection } \\
\text { elements } \\
\text { only }\end{array}$ & $\begin{array}{l}\text { Adherence forces } \\
\text { +connection } \\
\text { elements }\end{array}$ \\
\hline \multicolumn{5}{|c|}{ Maximum values: vertical loads / seismic loads $* * *$} \\
\hline $\begin{array}{l}\text { Periods of free vibrations, sec: } \\
T_{1} \\
T_{2} \\
T_{3}\end{array}$ & $\begin{array}{l}/ 0.229 \\
/ 0.148 \\
/ 0.146\end{array}$ & $\begin{array}{l}/ 0.152 \\
/ 0.093 \\
/ 0.075 \\
\end{array}$ & $\begin{array}{l}/ 0.156 \\
/ 0.100 \\
/ 0.099 \\
\end{array}$ & $\begin{array}{l}/ 0.152 \\
/ 0.093 \\
/ 0.075 \\
\end{array}$ \\
\hline $\begin{array}{l}\text { Maximum displacements , mm: } \\
\text { - vertical, w } \\
\text { - horizontal, u }\end{array}$ & $\begin{array}{l}2.22 / \\
11.02 / 11.02\end{array}$ & $\begin{array}{l}1.64 / \\
6.66 / 4.16\end{array}$ & $\begin{array}{l}0.68 / \\
4.34 / 4.39\end{array}$ & $\begin{array}{l}0.49 / \\
4.13 / 4.13\end{array}$ \\
\hline $\begin{array}{l}\text { Max. membrane stresses in stone dome, } \\
\text { MPa } \\
\text { - in meridian direction: } \\
\sigma_{\mathrm{Ny}}(+) \\
\sigma_{\mathrm{Ny}}(-) \\
\text { - in ring direction: } \\
\sigma_{\mathrm{Nx}}(+) \\
\sigma_{\mathrm{Nx}}(-)\end{array}$ & $\begin{array}{l}0.137 / 0.069 \\
0.540 / 0.083 \\
0.009 / 0.379 \\
0.138 / 0.213\end{array}$ & $\begin{array}{l}-0.030 / 0.108 \\
0.127 / 0.044 \\
0.008 / 0.075 \\
0.040 / 0.124\end{array}$ & $\begin{array}{l}-0.034 / 0.044 \\
0.293 / 0.038 \\
0.004 / 0.103 \\
0.047 / 0.092\end{array}$ & $\begin{array}{l}-0.030 / 0.108 \\
0.216 / 0.046 \\
0.001 / 0.124 \\
0.004 / 0.075\end{array}$ \\
\hline $\begin{array}{l}\text { Maximum bending stresses in stone dome, } \\
\text { MPa } \\
\text { - in meridian direction: } \\
\mathrm{m}_{\mathrm{y}}(+) \\
\mathrm{m}_{\mathrm{y}}(-) \\
\text { - in ring direction: } \\
\mathrm{m}_{\mathrm{x}}(+) \\
\mathrm{m}_{\mathrm{x}}(-)\end{array}$ & $\begin{array}{l}0.079 / 0.294 \\
0.024 / 0.046 \\
0.033 / 0.185 \\
0.017 / 0.017\end{array}$ & $\begin{array}{l}0.051 / 0.150 \\
0.060 / 0.046 \\
0.024 / 0.077 \\
0.026 / 0.006\end{array}$ & $\begin{array}{l}0.100 / 0.241 \\
0.135 / 0.184 \\
\\
0.026 / 0.112 \\
0.055 / 0.005\end{array}$ & $\begin{array}{l}0.038 / 0.151 \\
0.060 / 0.049 \\
0.013 / 0.077 \\
0.027 / 0.066\end{array}$ \\
\hline $\begin{array}{l}\text { Internal forces in stone ring beam : } \\
\mathrm{N}, \mathrm{kN} \\
\mathrm{Q}, \mathrm{kN} \\
\mathrm{M}, \mathrm{kN} \cdot \mathrm{m}\end{array}$ & $\begin{array}{l}202.0 / 320.0 \\
4.3 / 32.0 \\
10.0 / 78.0\end{array}$ & $\begin{array}{l}83.7 / 169.0 \\
4.3 / 17.1 \\
10.0 / 43.0\end{array}$ & $\begin{array}{l}88.0 / 156.0 \\
5.4 / 26.5 \\
12.5 / 62.0\end{array}$ & $\begin{array}{l}83.4 / 169.0 \\
4.3 / 17.1 \\
10.0 / 43.0\end{array}$ \\
\hline $\begin{array}{l}\text { Maximum stresses in surface of contact, } \\
\mathrm{kN} / \mathrm{m}^{2}: \\
\sigma_{\mathrm{z}} \\
\tau_{\mathrm{xy}}\end{array}$ & $\begin{array}{l}- \\
-\end{array}$ & $\begin{array}{l}193 \\
35\end{array}$ & - & $\begin{array}{l}152 \\
38\end{array}$ \\
\hline $\begin{array}{l}\text { Maximum values of internal forces in } \\
\text { connection elements, } \mathrm{kN} \text { : } \\
\text { - axial forces, } \mathrm{N}_{\mathrm{z}} \\
\text { - shear forces, } \mathrm{N}_{\mathrm{x}}\end{array}$ & $\begin{array}{l}- \\
-\end{array}$ & $\begin{array}{l}- \\
-\end{array}$ & $\begin{array}{l}315.0 / 143.0 \\
118.0 / 144.0\end{array}$ & $\begin{array}{l}119.0 / 145.0 \\
15.0122 .0\end{array}$ \\
\hline
\end{tabular}

Remarks:

* Load from weight of stone dome

** Load from weight of reinforced concrete shell + weight of stone dome

*** Ground acceleration $-0.4 \mathrm{~g}$ 

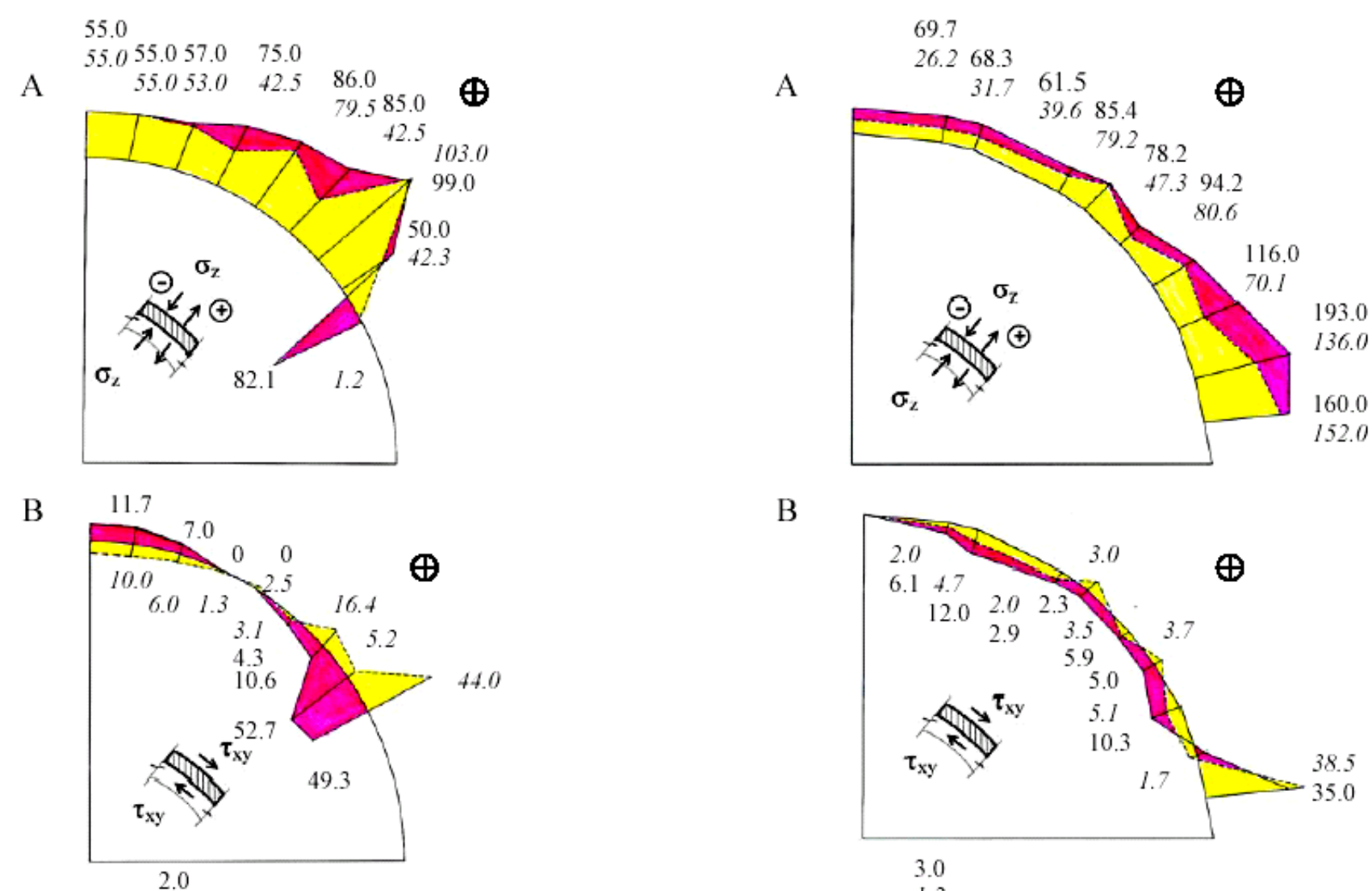

$\mathrm{B}$

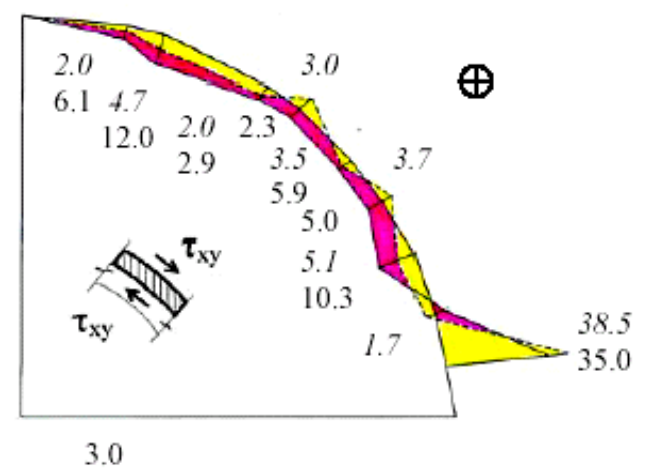

$\mathrm{C}$
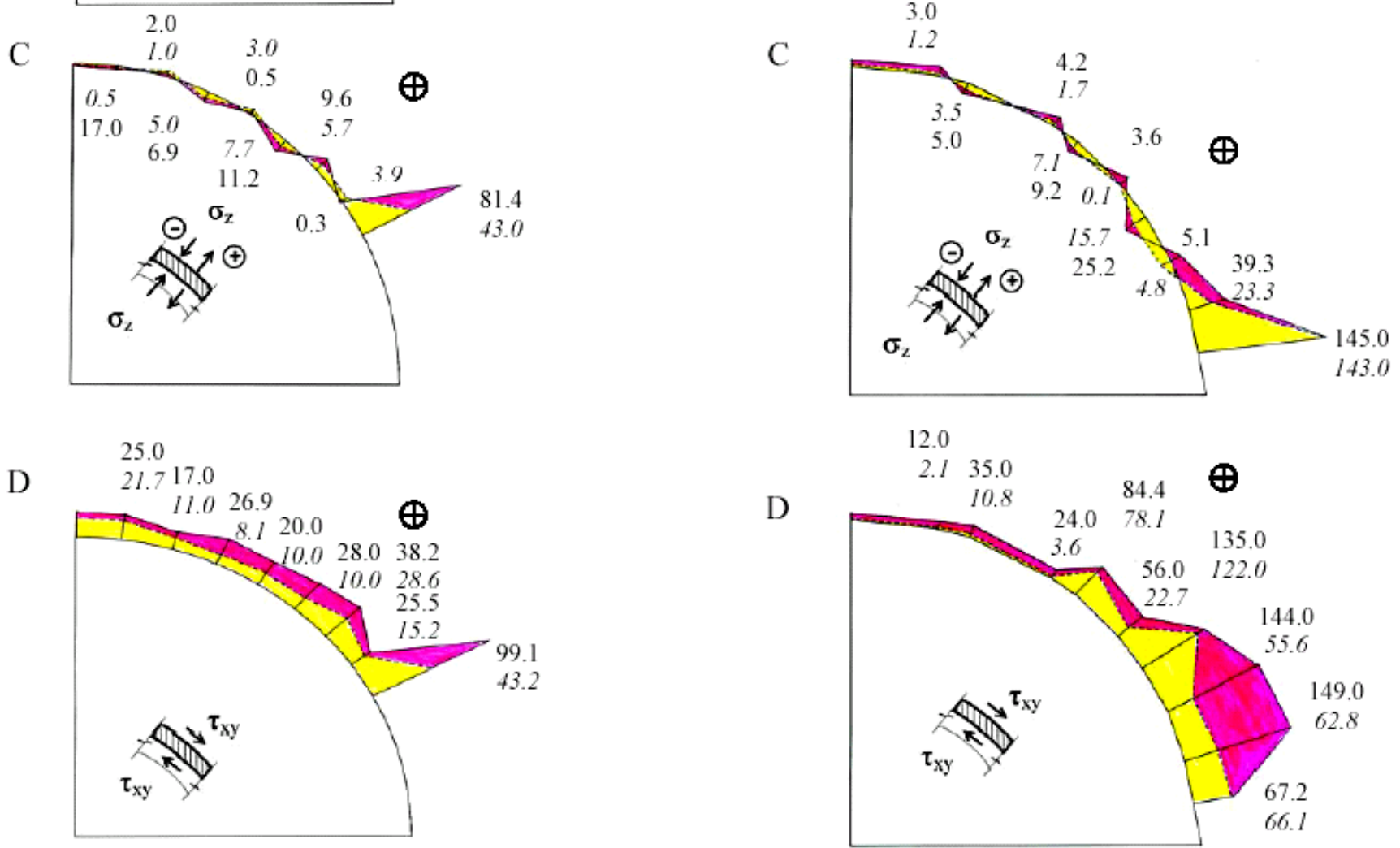

Fig-7: Stone dome connected with concrete shell

a - dome in Akhalthsikhe; b - similar to Hagia Sophia dome A, B - vertical loads; C, D - seismic loads.

$\sigma_{\mathrm{Z}}-$ normal stresses, $\mathrm{kPa} ; \tau_{\mathrm{xy}}-$ shear stresses, $\mathrm{kPa}$;

adherence forces only;
adherence forces + connection elements 
Table -3: Main results of structural analysis: maximum values of internal forces in connections. Interconnected structures

\begin{tabular}{|c|c|c|c|c|c|c|}
\hline \multirow[b]{2}{*}{ No } & \multirow[b]{2}{*}{$\begin{array}{l}\text { Ring } \\
\text { No }\end{array}$} & \multirow[b]{2}{*}{$\begin{array}{l}\text { Number of } \\
\text { connections } \\
\text { of ring }\end{array}$} & \multicolumn{4}{|c|}{ Forces, t (axial R*/shear S) } \\
\hline & & & $\begin{array}{l}\text { Thermal load } \\
\text { uniform } \Delta \mathrm{t}=+20^{\circ}\end{array}$ & $\begin{array}{l}\text { Thermal load } \\
\text { non-uniform } \\
\Delta \mathrm{t} 1=+10^{\circ} \\
\Delta \mathrm{t} 2=-10^{\circ}\end{array}$ & Vertical loads** & Seismic loads $* * *$ \\
\hline \multicolumn{7}{|c|}{ Dome in Akhaltsikhe (total number of connections 44) } \\
\hline 1 & 1 & 16 & $+3.5 / \pm 13.5$ & $-3.23 / \pm 12.0$ & $+1.8 / \pm 1.72$ & $\pm 0.285 / \pm 3.75$ \\
\hline 2 & 2 & 16 & $+4.22 / \pm 6.90$ & $-5.99 / \pm 10.35$ & $+3.5 / . \pm 0.25$ & $\pm 0.255 / \pm 2.92$ \\
\hline 3 & 3 & 8 & $+5.12 / \pm 4.41$ & $-7.55 / \pm 7.34$ & $+6.8 / \pm 0.44$ & $\pm 0.20-/ \pm 1.60$ \\
\hline 4 & 4 & 4 & $+6.04 / \pm 2.65$ & $-8.42 / \pm 4.01$ & $+12.9 / \pm 0.78$ & $\pm 0.075 / \pm 2.34$. \\
\hline \multicolumn{7}{|c|}{ A similar to Hagia Sophia dome (total number of connections 94) } \\
\hline 5 & 1 & 24 & $+34.1 /+22.1$ & $+12.9 /-6.0$ & $+24.7 / \pm 65.9$ & $\pm 1.4 / \pm 13.8$ \\
\hline 6 & 2 & 24 & $-24.6 /-34.7$ & $+18.4 /+6.3$ & $+13.9 / \pm 24.6$ & $+1.1 / \pm 7.1$ \\
\hline 7 & 3 & 16 & $+41.5 /-41.2$ & $-23.2 /+22.7$ & $+15.5 / \pm 22.0$ & $\pm 21.8 / \pm 21.6$ \\
\hline 8 & 4 & 12 & $+12.8 /+17.5$ & $-24.5 /-21.3$ & $+17.1 / \pm 17.7$ & $\pm 6.3 / \pm 6.6$ \\
\hline 9 & 5 & 12 & $+14.3 /+22.4$ & $-19.3 /-12.2$ & $+11.2 / \pm 14.2$ & $\pm 2.4 / \pm 3.0$ \\
\hline 10 & 6 & 6 & $+19.1 /+29.6$ & $-21.9 /-8.4$ & $+11.1 / \pm 13.0$ & $\pm 0.5 / \pm 2.2$ \\
\hline
\end{tabular}

Remarks:

* Resulting, in direction perpendicular to connection axis

**Load from weight of reinforced concrete shell + weight of stone dome

$* * *$ Ground acceleration $-0.4 \mathrm{~g}$

a

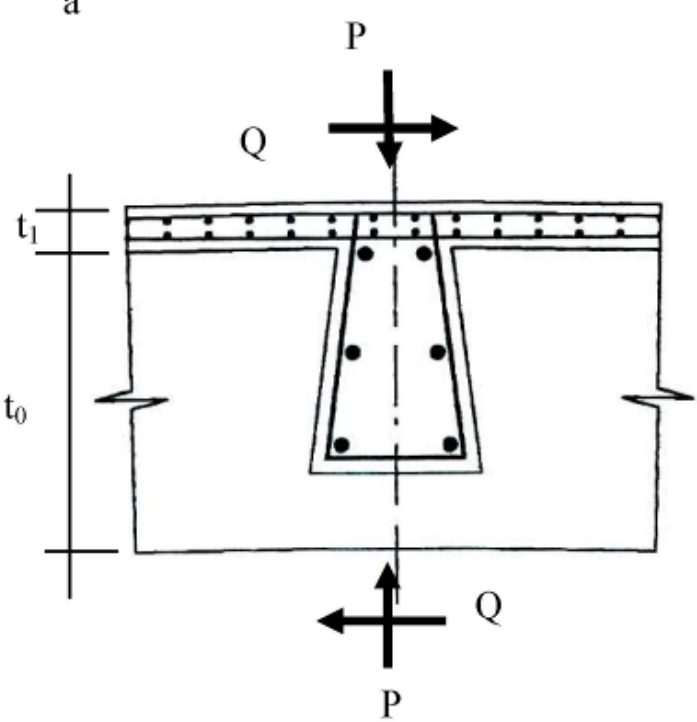

$\mathrm{b}$

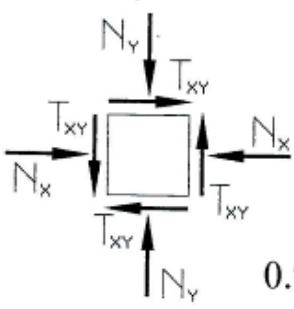

$\mathrm{n} \times \mathrm{O}$

$0.9 \cdot 10^{-4}$

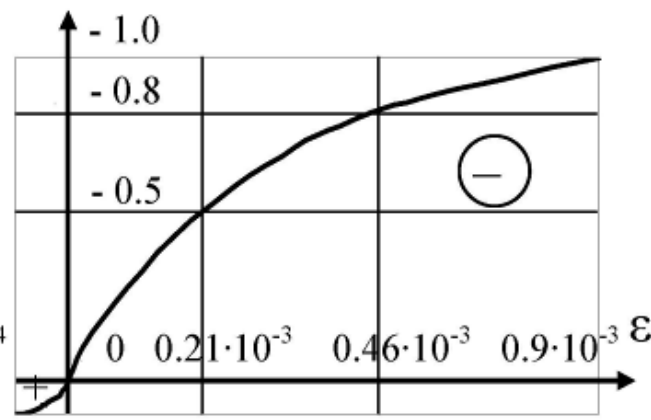

0.1

Fig-8: Non-linear finite element structural analysis for fragment of connection zone $\mathrm{a}$ - scheme of loads; $\mathrm{b}$ - components of stress states; $\mathrm{c}$ - diagram $\sigma-\varepsilon$ of materials: for stone $(n=1)$ and for concrete $(n=10)$ 

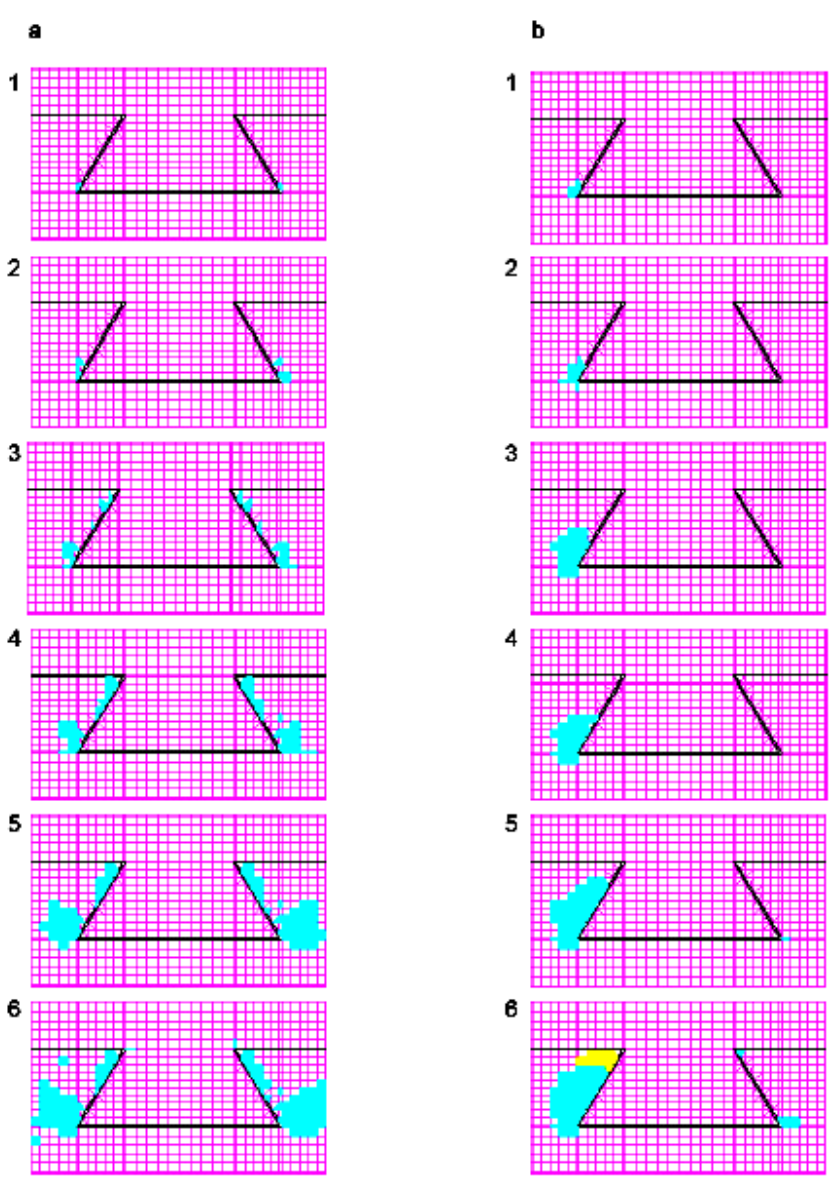

Fig-9: Stress concentration problem. Connection zone fragment. Non-linear analysis

Development of failure regions versus applied load level.

a - axial loading: $\mathrm{P}=500 \mathrm{kN} .1-$ step 3, P3 = 0.2P; 2 - step 7, P7 = 0.4P; 3 - step 11, P11 = 0.6P; 4 - step 14, P14 = 0.75P; 5 step $18, \mathrm{P} 18=0.89 \mathrm{P} ; 6-$ step $26, \mathrm{P} 26=\mathrm{P}$.

$\mathrm{b}$ - pure shear loading: $\mathrm{Q}=500 \mathrm{kN} .1-$ step 2, $\mathrm{Q} 2=0.4 \mathrm{Q}$;

2 - step 7, Q7 = 0.7Q; $3-$ step 12, Q12 $=0.8 \mathrm{Q}$;

$4-$ step 16, Q16 $=0.84 \mathrm{Q} ; 5-$ step 20, Q20 $=0.88 \mathrm{Q}$;

$6-$ step 22, Q22 $=0.9 \mathrm{Q}$.

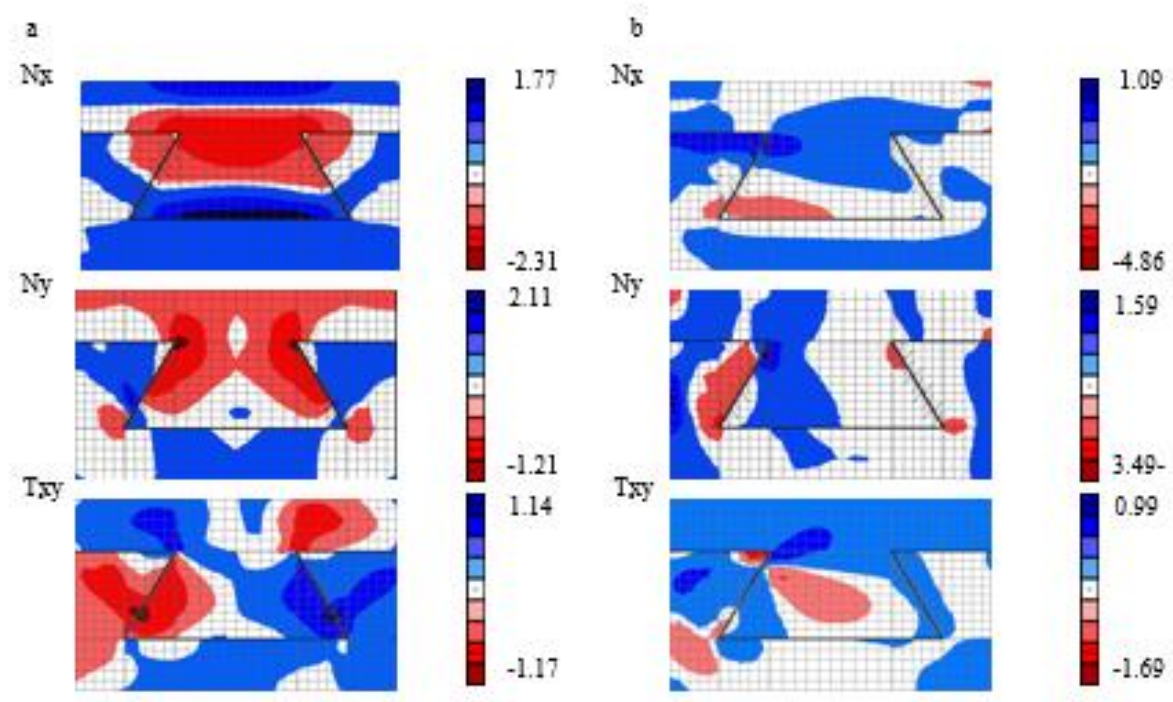

Fig-10: Problem of stress concentration. Fragment of connection zone. Non-linear analysis.

Distribution of normal (Nx, Ny) and shear (Txy) stresses, MPa

$\mathrm{a}-\operatorname{axial} \operatorname{load}(\mathrm{P}=500 \mathrm{kN}) ; \mathrm{b}-\operatorname{shear} \operatorname{load}(\mathrm{Q}=500 \mathrm{kN})$ 
It was found that stresses in a stone dome could reach high values for zones near concrete connection elements. Therefore, it could be recommended to provide special preliminary preparation of a stone surface for the zones of connection elements. For example, concrete spraying of high-strength material (with compression-breaking stress $200 \mathrm{~kg} / \mathrm{cm}^{2}$ and more) with a thickness of $2-3 \mathrm{~cm}$ could be used.

\section{CONCLUSIONS}

An original dome strengthening structure is proposed to enable durability of ancient domes against seismic forces during severe earthquakes without significant damage, and at the same time to preserve the existing ancient appearance of the inner surface in its present state of antiquity. It consists of a new thin-walled reinforced concrete shell with a supporting ring, cast on top of the existing stone dome. The connection between old stone dome and new reinforced concrete shell (structure of strengthening) is achieved by using special reinforced concrete connecting elements and by adhesion of the neighboring surfaces. The concrete connecting elements protrude as pins out of the reinforced concrete shell, have the form of a truncated pyramid, and penetrate into the stone dome. They are distributed throughout the entire surface of the strengthened dome. Thus, an "interconnected stone-reinforced concrete structure" is created. The efficiency of the proposed method is shown by numerical analysis of vertical, thermal, and seismic loads with the use of FEM, on examples of Akhalthsikhe and of one similar to Hagia Sophia stone domes. Its essence lies in: the potential regulation of the stress-strain state of the stone dome by means of changing the quantity and location of connecting members; stresses and strain in the stone dome are significantly decreased; supporting constructions are significantly unloaded due to the decrease of the horizontal forces, as the thrust is wholly absorbed by the reinforced concrete supporting ring. As a result, the earthquake resistance of the stone domes increases significantly.

\section{ACKNOWLEDGEMENTS}

The authors are thankful to the Dr. G. Sirotin (Ariel University, Ariel, Israel) for his assistance in preparing this article for publication.

\section{REFERENCES}

[1]. Mark R, Westagard A. The first dome of the Hagia Sophia: myth vs. technology. Domes from Antiquity to the Present. Proc. of the IASS-MSU Int. Symposium. Istanbul, 1988, pp. 163-172.

[2]. Meyer-Christian W. Hagia Sophia, the engineers planning of Anthemios and Isidoros. Proc. of the IASSMSU Int. Symposium. Istanbul, 1988, pp. 173-190.

[3]. Sundaram R. Historic dome built in south India during $17^{\text {th }}$ century. Proc. of the IASS-MSU Int. Symposium. Istanbul, 1988, pp. 205-215.
[4]. Pizzetti and Fea. Restoration and strengthening of the elliptical dome of Vicoforte Sanctuary. Proc. of the IASSMSUInt.Symposium.Istanbul,1988, pp. 289-308.

[5]. Heyman J. The stone skeleton - structured engineering of masonry architecture. Cambridge University Press, 1995, 252. pp.

[6]. Krautheimer R., Ćurčić S. Early Christian and Byzantine architecture. Penguin Books Ltd., 1986, 350 pp.

[7]. Harries K. A. Quake resistance in ancient Rome. Concrete International, 19 (1), 1997, pp. 55-58.

[8]. Structural Analysis of Historical Constructions, $5^{\text {th }}$ International Conference New Delhi, India, 2006

[9]. Penelis G., Karavesiroglou M., Stylianidis K, Leontaridis D. The Rotunda of Theassaloniki: seismic behavior of Roman and Byzantine structures. Hagia Sophia from the Age of Justinian to the Present. Edited by Mark R. and A. Ş. Calmak. Cambridge University Press, 1992, pp. 132-157.

[10]. Danieli (Danielashvili) M., Gabrichidze G., Goldman A., Sulaberidse O. Experience in restoration and strengthening of stone made ancient domes in seismic regions. Proc. of 7th US NCEE, Boston, Massachusetts, USA, vol. II, 2002, pp. 1167-1175.

[11]. Sesigur H., Celik O.C., Cili F. Repair and strenghening of ancient structures. First European Conference on Earthquake Engineering and Seismology, Geneva, Switzerland, 2006, paper No1387.

[12]. Poland C.D, Reis E.M.The repair and strengthening of historic Stanford Memorial Church. Tenth World Conference. Balkema, Rotterdam, 1992, pp. 5341-5346.

[13]. Gabrilovich P., Richard P. Methodology for strengthening and repair of earthquake damaged monuments in Pagan- Burma. Proc. of Eight World Conference on Earthq. Engin., San- Francisco, USA, vol. 1, 1984, pp. 609616.

[14]. Rabin I.S. Structural analysis of historic buildings: restoration, preservation and adaptive application for architects and engineers. Hancobci J. Wiley \& Sons. 2000. 240 pp.

[15]. Repair and strengthening of historical monuments and buildings in urban nuclei. Building construction under seismic conditions in the Balkan region, UNDP/UNIDO project rep/79/015. Vienna. 1984, $296 \mathrm{pp}$

[16]. Ziyaeifar M., Meshki H., Rajaei M. Rehabilitation of historical buildings subjected to seismic hazards, a methodology. $13^{\mathrm{th}}$ World Conference on Earthquake Engineering. Vancouver, B.C., Canada, 2004, paper No. 1598.

[17]. Sofronie R.A., Crisan R., Toanchina M. Retrofitting the masonry of cultural heritage. Fifth National Conference on Earthquake Engineering, 2003, Istanbul, Turkey, paper No. AE-013, (SD R).

[18]. Danieli M., Bloch J. . Rehabilitation of the religious heritage in seismic regions: Principle and practice. Protection of Historical Buildings. PROHITECH 09.Proceedings of the international conference on protection of historical buildings, PROHITECH 09, Rome, Italy, 21 24 June 2009, Ed. Federico M.Mazzolani, vol. 1,CRC, Press/Balkema, 2009 Taylor \& Francis Group, London, UK, pp. 125-130. 
[19]. Danieli M., Bloch J. Principle, practice and experience of rehabilitation of the historical buildings in seismic regions. In: Proceedings of the 15th World Conference on Earthquake Engineering (15WCEE), September,24-28, 2012, Lis A.bon, Portugal, pp.1-9, Paper No 392.

[20]. Danieli M, Aronchik . Case study: The strengthening and seismic safety of the Oni synagogue in Georgia. In: Proceedings of the 13th International Conference on Structures under Shock and Impact (SUSI XIII). WIT Press, 2014, pp. 456-466.

[21]. Paret T.,Freeman S.,Searer G., Hachem M., Gilmarin U. Seismic evaluation and strengthening of an historic synagogue using traditional and innovatie methods and materials. First European Conference on Earthquake Engineering and Seismology, Geneva, Switzerland, 2006, paper No 701 .

[22]. Danielashvili M., Gabrichidze G., Melashvili Y., Sulaberidze O. Study of some reinforced and metal spatial structures in seismic regions of Georgia. Proc ICSS-98, vol. I, Moscow, 1998, pp. 396-403.

[23]. Engineering Analysis of the Racha Earthquake Consequences in Georgia, 1991. Editor Gabrichidze G., Metsniereba, 1996, Tbilisi, Georgia. 235 pp.

[24]. Emerson W. and Van Nice, R. L. Hagia Sophia, Istanbul: Preliminary report of a recent examination of the structure. Supplement to American Journal of Archaeology, 1943, Volume XLVII, pp. 403-416.

[25]. Kato S., Aoki T.,Hidaka K., Nakamura H. Finiteelement modeling of the first and second domes of Hagia Sophia. Hagia Sophia from the Age of Justinian to the Present. Edited by Mark R. and A. Ş. Calmak. Cambridge University Press, 1992, pp. 103-119.

[26]. Mark R., Çacmac A.Ş. Preliminary report on an integrated study of the structure of Hagia Sophia: past, present and future. Hagia Sophia from the Age of Justinian to the Present. Edited by Mark R. and A. Ş. Calmak. Cambridge University Press, 1992,. 120-130.

[27]. Mainstone R.J. Questioning Hagia Sophia. Hagia Sophia from the Age of Justinian to the Present. Edited by Mark R. and A. Ş. Calmak. Cambridge University Press, 1992, pp. 158-176.

[28]. Aoki T., Kato S., Ishikawa K., Hidaka K., Yorulmaz M., Gili F. Principle of structural restoration for Hagia Sophia Dome. Proc. of STREMAH Int. Symposium, San Sebastian, 1997, 6, pp. 467-476.

[29]. Aoki T., Chiorino M., Roccani R. Structural characteristics of the elliptical masonry dome of the Sanctuary of the Vicoforte. Proc. of the First International Congress on Construction History, 2003, Madrid

[30]. Timoshenko S. Strength of materials. Part II. 3rd edition. Toronto, New York, London. 1956. 360 pp.

[31]. Danieli (Danielashvili) M., Zaalishvili L. Correlation of seismic activity with the architectural-historical inheritance in the northern Georgia. First European Conference on Earthquake Engineering and Seismology, Geneva, Switzerland, 2006, paper No: 1303, (SD-R).

[32]. Karaesmen E., Unay A.I., Erkay C., Boyaci N. Seismic behavior of old masonry structures. Earthquake Engineering. Tenth World Conference. Balkema, Rotterdam, 1992, pp. 4531-4536.
[33]. Cuadra C., Karkee M.B., Ogava J., Rojas J. An evaluation of earthquake risk to Inca's historical constructions. $13^{\text {th }}$ World Conference on Earthquake Engineering. Vancouver, B.C., Canada, 2004, paper No.150 (SD-R).

[34]. Timoshenko S.P., Woinovsky-Kriger S. Theory of plates and shells. 2nd edition. McGraw-Hill, New York, Toronto, London, 350 pp. 1959

[35]. Akhvlediani N.A., Danielashvili M.A. Limit analysis of reinforced concrete shells, Arkhivum Inzynezii Ladowey, Tom XXXVI, Z 3, Warsaw, Poland, 1990, pp. 187-205.

[36]. Danieli (Danielsvilli) M., Aronchik A, Bloch,. J. Seismic safety of an ancient stone dome strengthened by an original method. $13^{\text {th }}$ World Conference on Earthquake Engineering. Vancouver, B.C., Canada, 2004, (SD-R) paper No 2789.

[37]. Bloch J., Aronchik A., Goldman A., Danieli (Danielashvili) M. A Method of Strengthening Ancient Domes and Vaults, and Problems of their Stress - Strain States in Seismic Regions. Wessex Institute of Technology, UK. ERES IV 22-24 September 2003, Ancona, Italy. Publl., In .HPSM 2004 WIT Press Southampton, Boston, 2004,611620

[38]. Balandin A., Geniev G. Strength theory of stone and concrete. Moscow, Stroizdat, 1972. 160 pp.

\section{BIOGRAPHIES}

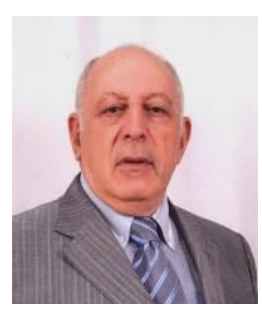

Dr. Moshe Danieli is a civil engineer, from GTU, Tbilisi (1961), Ph.D from GPEHTBI, Tbilisi (1972), Senior scientist in Strength of Materials and Structural Mechanics, from ASSU, Moscow (1977). Since 2002 he is a senior lecturer in the Dept of Civil Engineering, Ariel University, Israel.

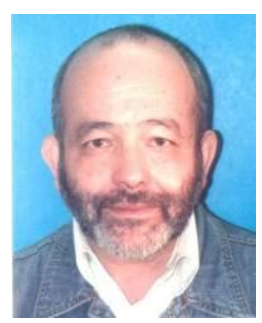

Arcady Aronchik is a structural engineer, Ph.D from Central Research Institute of Building Structures (TCNIISK), Moscow, Russia (1981), MSc from Riga Technical University (RTU), Latvia, (1971). He deals with structural FEM analysis and the design of civil and industrial buildings.

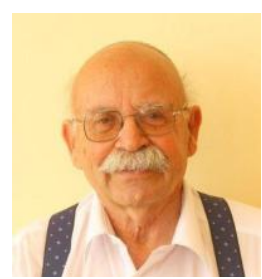

Dr. Jaacov Bloch is a civil engineer (B.Sc., 1962, M.Sc., 1964) from Technion, Israel, Dr.Sc., 1974. He founded the Department of Civil Engineering at the Ariel College of Samaria (Ariel University at present) and headed the Department for 12 years. Dr. J. Bloch is currently an associate professor. 